\title{
DATA FOR THE EVALUATION OF HYDROGEN RISKS ONBOARD VEHICLES: OUTCOMES FROM THE FRENCH PROJECT DRIVE
}

\author{
Olivier GENTILHOMME ${ }^{1}$, Christophe PROUST ${ }^{1,2}$, Didier JAMOIS ${ }^{1}$, Isabelle \\ TKATSCHENKO ${ }^{3}$, Benjamin CARITEAU ${ }^{3}$, Etienne STUDER ${ }^{3}$, Franck MASSET ${ }^{4}$, Guillaume $^{2}$ \\ JONCQUET $^{4}$, Muriel AMIELH ${ }^{5}$ and Fabien ANSELMET ${ }^{5}$
}

\begin{abstract}
${ }^{1}$ INERIS (National Institute of Industrial Environment and Risks), Parc Technologique Alata BP 2 - 60550 Verneuil en Halatte (France), e-mail: olivier.gentilhomme@ineris.fr

${ }^{2}$ UTC (Technological University of Compiègne), Centre Pierre Guillaumat - TIMR bat. E-D 60200 Compiègne (France), e-mail: christophe.proust@ineris.fr

${ }^{3}$ CEA (Atomic Energy Commission), CEA Saclay, DANS/DM2S/SFME bat. 454 - Point Courrier 47 - 91191 Gif-sur-Yvette (France), e-mail : isabelle.tkatschenko@ cea.fr

${ }^{4}$ PSA PEUGEOT CITROËN, Centre Technique de Carrières-sous-Poissy 212 bd Pelletier 78955 Carrières-sous-Poissy (France), e-mail : franck.masset@ mpsa.com

${ }^{5}$ IRPHE (Research Institute on Unstable Phenomena), Technopôle de Château Gombert - 49

rue Frédéric Joliot Curie - BP 146 - 13384 Marseille (France), e-mail : anselmet @irphe.univmrs.fr
\end{abstract}

\begin{abstract}
From 2006 to 2009, INERIS alongside with CEA, PSA PEUGEOT CITROËN and IRPHE were involved in a project called DRIVE. Its objective was to provide data on the whole reaction chain leading to a hydrogen hazard onboard a vehicle. Out of the three types of leakages identified by the consortium (permeation, chronic and accidental), the chronic leakage taking place within the engine was judged to be more problematic since it can feature a high probability of occurrence and a significant release flow rate (up to $100 \mathrm{NL} / \mathrm{min}$ ). Ignition tests carried out within a real and dummy engine compartment showed that pressure effects due to an explosion will be relatively modest provided the averaged hydrogen concentration in this area is limited to $10 \% \mathrm{vol} / \mathrm{vol}$, which would correspond to a maximum release flow of $10 \mathrm{NL} / \mathrm{min}$. This maximum concentration could be used as a threshold value for detection or as a target while designing the vehicle. Jet fire experiments were also conducted in the frame of the DRIVE project. It was found that pressure-relief devices (PRDs) might be unsuited to protect humans from the explosion of a tank caused by a bonfire. Other solutions are proposed in this paper.
\end{abstract}

\subsection{INTRODUCTION}

Hydrogen is currently used in many industrial applications. Should it become more extensively used in the transport industry, it is thought that the safety procedures and technologies already existing for the industry will provide only limited guidance for hydrogen-powered vehicle. That is because hydrogen will be used within a decentralised infrastructure (= vehicle), in relatively small amount (= several $\mathrm{kg}$ per user) and by a large population without special training in the safety of this flammable gas [1].

Hydrogen is already being used in different ways to power vehicles [2]: to produce electricity in a fuel cell (e.g. DaimlerChrysler F-Cell, Toyota FCHV, Hyundai Santa Fe, Suzuki WagonR FCV...), to replace gasoline or diesel fuel in the internal combustion engine (e.g. BMW 745H, Ford Focus C-Max, Ford Model U, Mazda RXB Renesis...)... To ensure that all these technologies can be used, it is important to identify as early as possible all risks associated with the use of hydrogen onboard vehicle and to succeed in mitigating them. However, only a small number of these vehicles are in operation today and that limits quite significantly the data available on safety aspects. 
The aim of the project DRIVE ${ }^{1}$ was to produce such data and especially (1) to quantify the leak rates likely to occur on the hydrogen circuit, (2) to investigate the resulting formation of explosive atmosphere in and out the vehicle, (3) to assess the likelihood of an engine component to ignite the flammable atmosphere and (4) to evaluate the consequences of an ignition (jet fire and explosion).

\subsection{LEAKAGE SCENARII AND RATES}

BARLEY [3] pointed out the difficulty of assessing the hydrogen leak arising from a hydrogenpowered vehicle ("The range and frequencies of occurrence of leakage rates that will occur with hydrogen vehicles are unknown to us, despite our literature search"). The published values are varying between $5 \mathrm{NL} / \mathrm{min}$ [4] and $1100 \mathrm{NL} / \mathrm{min}$ [5] with an average of approximately 100$200 \mathrm{NL} / \mathrm{min}$ [6]. Since this scattering only highlights the diversity of the leakage conditions, the DRIVE consortium first tempted to classify the leakage (Table 1).

Table 1. Leak classification proposed by DRIVE.

\begin{tabular}{|c|c|c|c|c|}
\hline Type & Origin & Occurrence & Release flow rate & Analytical tool? \\
\hline $\begin{array}{c}\text { Permeation } \\
\text { leakage }\end{array}$ & $\begin{array}{c}\text { Inherent to the } \\
\text { smallness of } \\
\text { the molecule }\end{array}$ & Permanently & $\begin{array}{c}\text { on the order of } \\
0,001 \mathrm{NL} / \mathrm{min}\end{array}$ & $\begin{array}{c}\text { [7] for permeation } \\
\text { through a metal }\end{array}$ \\
\hline $\begin{array}{c}\text { Chronic } \\
\text { leakage }\end{array}$ & $\begin{array}{c}\text { Ageing of the } \\
\text { vehicle }\end{array}$ & Frequent & No idea & No \\
\hline $\begin{array}{c}\text { Accidental } \\
\text { leakage } \\
\text { vehicle or } \\
\text { failure in the } \\
\text { process or } \\
\text { storage } \\
\text { equipment }\end{array}$ & Rare & $\geq 100 \mathrm{NL} / \mathrm{min}$ & [7], [8] ... \\
\hline
\end{tabular}

Permeation arises because of molecular diffusion through the walls of a pressurized vessel: it increases with increasing storage pressure and material temperature. Since permeation is related to the smallness of the hydrogen molecule, it can affect all materials. As mentioned by [9], the permeation rate can be considered negligible for metallic containers or containers with metallic liners (commonly known as Types 1, 2 or 3). However, hydrogen permeation could be an issue, and therefore requires attention, for containers with non-metallic liners (Type 4). To the author's knowledge, analytical tool to calculate the release flow rate only exists when permeation takes place through a pure metal. Under this condition, the release flow rate can be calculated using [7]. Typical values are on the order of $0,001 \mathrm{NL} / \mathrm{min}$. With such small leakage rate, the probability of a hazardous situation is negligible.

The accidental leakage arises because of a collision with the vehicle or a failure in the process or storage equipment. The release mass flow rate could be straightforwardly estimated (see [7] or [8]). Typical values can be well above $100 \mathrm{NL} / \mathrm{min}$. Such event might generate a fire or an explosion but the probability of occurrence is normally very low.

\footnotetext{
${ }^{1}$ DRIVE (2006-2009) stands for Experimental Data for the Evaluation of Hydrogen Risks, for the validation of numerical tools and the Edition of guidelines. This project gathered CEA, PSA PEUGEOT CITROEN, IRPHE and INERIS.
} 
However, one has to wonder whether the ageing of vehicle or the succession of maintenances during its life will affect significantly the sealing performance of the line. This results in a so-called chronic leakage that is very difficult to preclude unless very disproportionate means are put in place as regards to the application. Moreover, there is no analytical tool in the literature to predict the leakage flow rate probably because of the diversity of the origins. This leakage might be hazardous since both its release flow rate and probability of occurrence could be significant.

To fill this knowledge gap, the leakage rates from key components of the hydrogen line were measured after they underwent various mechanical and thermal solicitations. The objective was to reproduce as realistically as possible the functioning or ageing of the components during the servicing life of the vehicle. The components were placed successively inside a 40-L chamber (Figure 1) which was partly filled with oil ${ }^{2}$ and thermally insulated. The components were fed with hydrogen at their operating pressures: from few bars for the components located close to the fuel cell (e.g. phase separator, one-way valve, hydrogen pump...) and up to hundreds of bars for those installed near the storage area (e.g. Staubli connection). Any leakage from the component would result in a pressure rise within the chamber that was measured by means of a differential pressure transducer. The accuracy of the facility was estimated to be less than $2.10^{-5} \mathrm{~cm}^{3} / \mathrm{s}$.

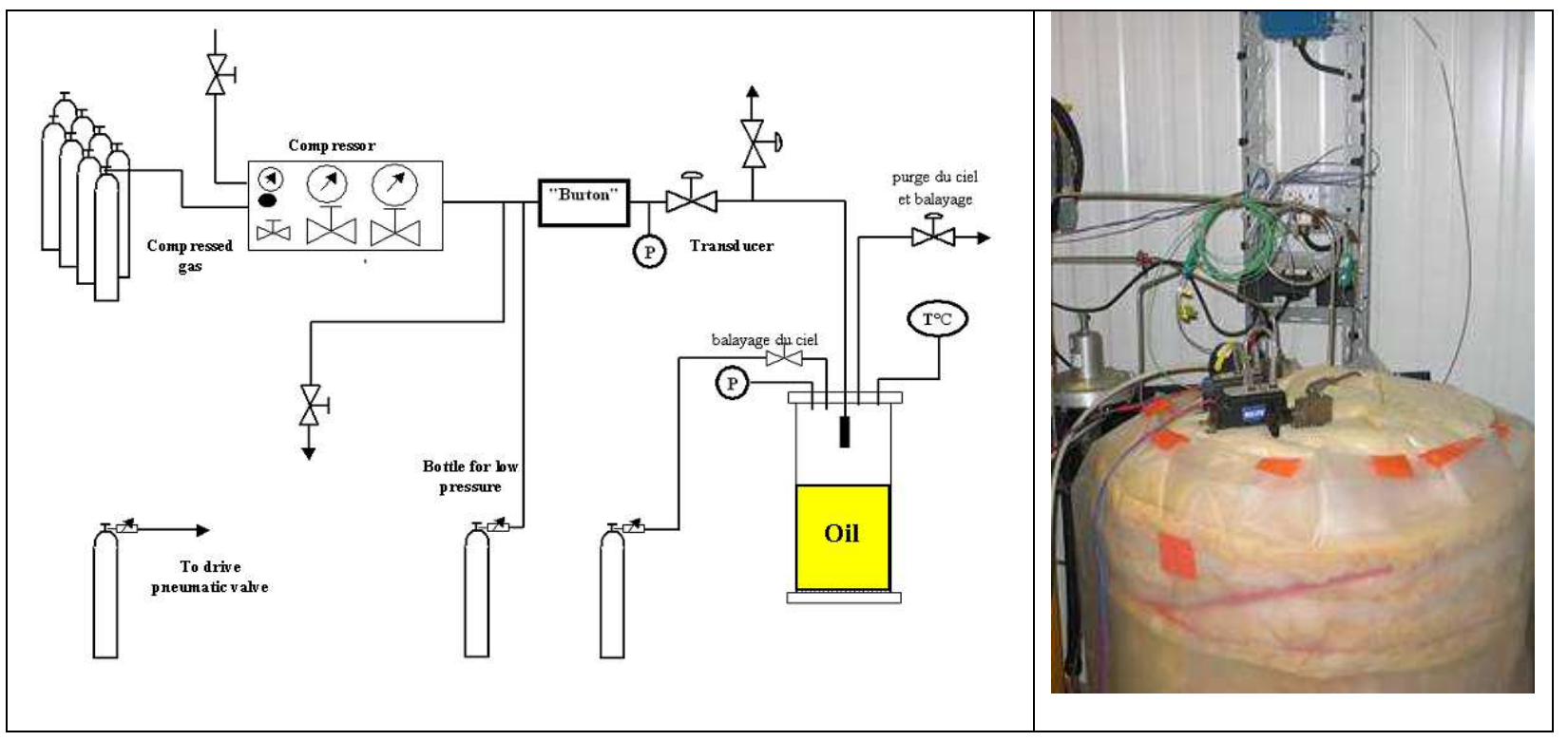

Figure 1. Facility used to measure chronic leakage

The results are listed in Table 2. A particular attention should be given to the maintenance because most of the leakages occurred from insufficient tightness. As an example, tightening a plug $1 / 2$ just by hand could lead to a leakage flow rate of $800 \mathrm{~cm}^{3} / \mathrm{s}$, when pressurised at 20 bars. This corresponds to a maximum mass flow rate of about $0,01 \mathrm{~kg} / \mathrm{s}$ under NTP conditions. It is also interesting to note that ageing seems to have very little effect on the sealing behaviour of the components.

\footnotetext{
${ }^{2}$ Oil was used to reduce the testing volume and to provide a steady thermal capacity so that the chamber temperature was constant.
} 
Table 2. Measured chronic leakage arising from key components of the hydrogen line.

\begin{tabular}{|c|c|c|c|c|}
\hline Component & $\begin{array}{c}\text { Test } \\
\text { Pressure }\end{array}$ & & Test protocol & $\begin{array}{c}\text { Leakage rate } \\
(\mathrm{L} / \mathrm{min})\end{array}$ \\
\hline \multirow{3}{*}{ Plug 1/2" } & \multirow{3}{*}{20 bar } & $1-$ & Normal tightening & $<2.10^{-5}$ \\
\hline & & 2- & Insufficient tightening (by hand) & 48 \\
\hline & & $3-$ & After 20 dismantling/re-assembly operations & $<2.10^{-5}$ \\
\hline \multirow{5}{*}{ Pipe fitting $1 / 4^{\prime \prime}$} & \multirow{3}{*}{20 bar } & $1-$ & Normal tightening & $<2.10^{-5}$ \\
\hline & & $2-$ & Normal tightening after an excessive one & $<2.10^{-5}$ \\
\hline & & 3- & With a mark in the fitting & 2,2 \\
\hline & 16 bar & 4- & With a mark in the fitting & 1,9 \\
\hline & 30 bar & 5- & With a mark in the fitting & 3,7 \\
\hline \multirow{2}{*}{$\begin{array}{l}\text { Quick-connect } \\
\text { coupling }\end{array}$} & \multirow{2}{*}{350 bar } & $1-$ & Normal connection & $<2.10^{-5}$ \\
\hline & & $2-$ & After 100 coupling operations & $<2.10^{-5}$ \\
\hline \multirow{2}{*}{ Elbow - 90 } & \multirow{2}{*}{3 bar } & $1-$ & Normal tightening & $<2.10^{-5}$ \\
\hline & & $2-$ & Thermal ageing & $<2.10^{-5}$ \\
\hline \multirow{2}{*}{ Polyamide tube } & \multirow{2}{*}{20 bar } & $1-$ & Normal tightening & $<2.10^{-5}$ \\
\hline & & $2-$ & Thermal ageing & $<2.10^{-5}$ \\
\hline Hydrogen pump & 3 bar & $1-$ & Normal tightening & $<2.10^{-5}$ \\
\hline Phase separator & 3 bar & $1-$ & Normal tightening & $<2.10^{-5}$ \\
\hline \multirow{2}{*}{ 1-way valve } & \multirow{2}{*}{3 bar } & $1-$ & Normal tightening & $<2.10^{-5}$ \\
\hline & & $2-$ & Thermal ageing +100 valve operations & $<2.10^{-5}$ \\
\hline \multirow{4}{*}{ Excess flow valve } & 5 bar & 1- & Normal tightening $($ pressure setting $=9$ bar $)$ & $1,2.10^{-3}$ \\
\hline & \multirow{3}{*}{7 bar } & 2- & Normal tightening $($ pressure setting $=9$ bar $)$ & $2,4.10^{-3}$ \\
\hline & & 3- & Normal tightening (pressure setting = 15 bar) & $1,5.10^{-3}$ \\
\hline & & 4- & Thermal ageing +100 valve operations & $1,6.10^{-3}$ \\
\hline \multirow{3}{*}{ Cap $1 / 2 "$} & \multirow{3}{*}{$20 \mathrm{bar}$} & $1-$ & Normal tightening & $<2.10^{-5}$ \\
\hline & & 2- & Insufficient tightening & 6 \\
\hline & & $3-$ & After 20 dismantling/re-assembly operations & $<2.10^{-5}$ \\
\hline
\end{tabular}

N.B.: these chronic leakages were measured at ambient temperature and pressure (i.e. $\mathrm{P}=101325 \mathrm{~Pa}$ and $\left.\mathrm{T}=25^{\circ} \mathrm{C}\right)$.

\subsection{FORMATION OF AN EXPLOSIVE ATMOSPHERE (ATEX)}

A hydrogen leakage occurring on a vehicle stationed in a domestic garage or a underground parking is certainly one of those situations where it is important to fully understand all the mechanisms leading up to the build-up of a potential ATEX. Most of the previous studies were interested in the resulting gas distribution within the garage or the parking [3, 9,10,11 or 12] but rarely in the vehicle itself. The DRIVE project produced more data in both environments.

The enclosure used during the experiments was built in CEA. It consisted of a rectangular box representative of a single-vehicle private garage with internal dimensions $\mathrm{L}=5.76,1=2.96$ and $\mathrm{H}=$ 2.42 (Figure 2). It was equipped with a tilting door at the front and an access door at the back. Most of these experiments were performed with a light commercial car of overall dimensions $L=4.14,1=1.96$ and $\mathrm{H}=1.81 \mathrm{~m}$. Different leakages in the range $0,05 \mathrm{NL} / \mathrm{min}$ to $600 \mathrm{NL} / \mathrm{min}$, hence covering the 
chronic and accidental leakages of Table 1, were simulated at various locations in the vehicle (in the engine compartment, under the chassis or in the storage area at the back of the vehicle) using helium rather than hydrogen for safety reasons. Concentrations were monitored within the different zones of the vehicle but also in the free volume of the garage by means of catharometers. More details regarding the testing facility can be found in [12], [13] or [14].

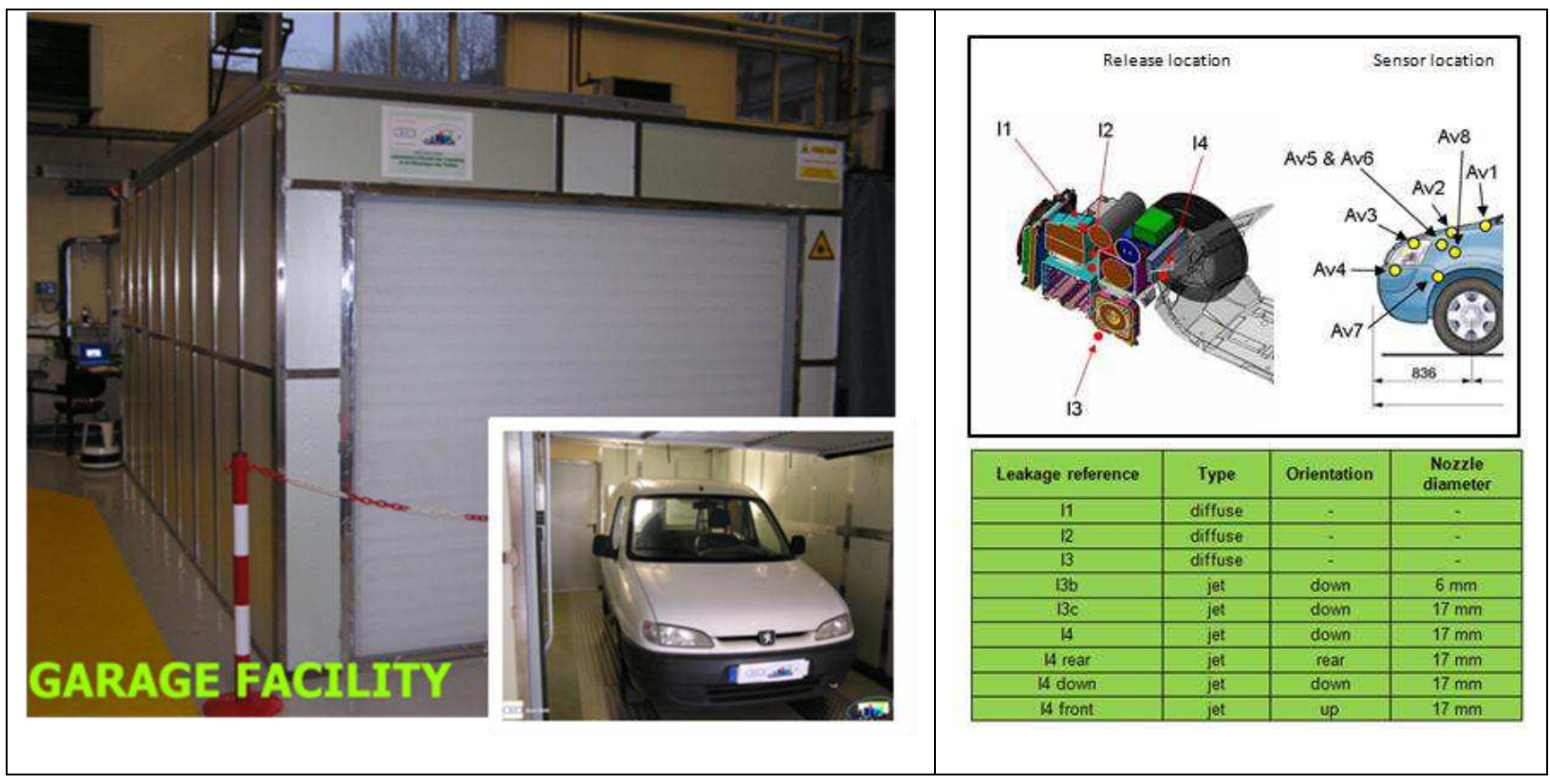

Figure 2. Garage facility used for dispersion experiments

Once the leakage started, the concentration in the engine rose sharply and then became approximately constant. This asymptotic value is referred to as the "saturated concentration". Figure 3 shows the variation of this concentration with the release flow rate for different types of chronic or accidental leakages (as a diffuse source I2, I3 or as a jet I3b, I3c).

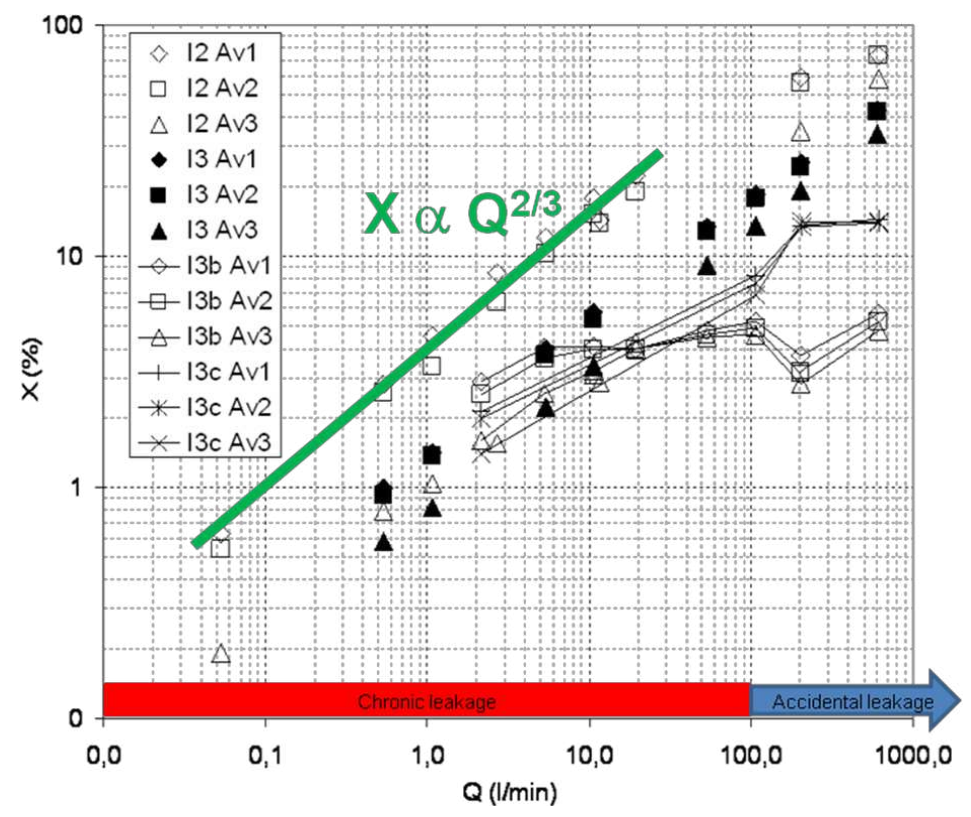

Figure 3. Saturation concentration measured in the engine compartment as a function of the accidental or chronic leakage 
A leakage in the engine compartment will produce a high momentum jet that is very likely to impact an obstacle. Thus several experiments were performed by placing a foam block at the exit of the release nozzle which was positioned at different heights within the engine (I2 and I3). This foam block was aimed at breaking the gas momentum. The saturated concentration depends on the volumetric flow rate and the source location relatively to the bonnet surface. The longer the distance from the bonnet, the better is the hydrogen dispersion. Similarly to hydrogen, helium is a buoyant gas and, as it rises towards the bonnet of the vehicle, it encounters a lot of obstacles hence promoting its dilution. Note that the saturated concentration follows a $2 / 3$ power law: this trend is representative of the "displacement regime" as identified by LINDEN [15].

If the leakage is non-impacting, the high momentum of the jet promotes dilution (I3b and I3c) and increases the volume of the mixing zone. Of particular interest is the very little dependency of the saturated concentration with the release flow rate for a downward jet: this could be interpreted using the theory of buoyant gaseous jets [12].

Note that the leakage may also appear under the vehicle or in the storage compartment. As underlined by MAEDA [16], the shape of the chassis plays an important role in gas dispersion. In overall, the released gas tends to migrate towards the engine and the storage compartment with a concentration smaller than $\mathrm{I} 2$ and $\mathrm{I} 3$.

\subsection{EXPLOSION OF THE ATEX INSIDE THE ENGINE COMPARTMENT}

MAEDA [16, 17] conducted ignition tests on a passenger car. After performing the same hydrogen release within the engine compartment as previously shown in this paper, they concluded that people around the vehicle would not be seriously directly injured even if the release flow rate was as high as $1000 \mathrm{NL} / \mathrm{min}$. To clarify this important issue, further tests were performed during the DRIVE project [18].

Phenomenological experiments were carried out using a transparent rig fully representative of an engine compartment (Figure 4). All faces were closed with the exception of the bottom one which was fully opened and located $200 \mathrm{~mm}$ above the ground (= ground clearance) and the front one where openings were drilled (= front grid). Transparent boxes were introduced to account for the presence of engine components (such as wings of the vehicle, fuel cell, electric motors, calculators...).

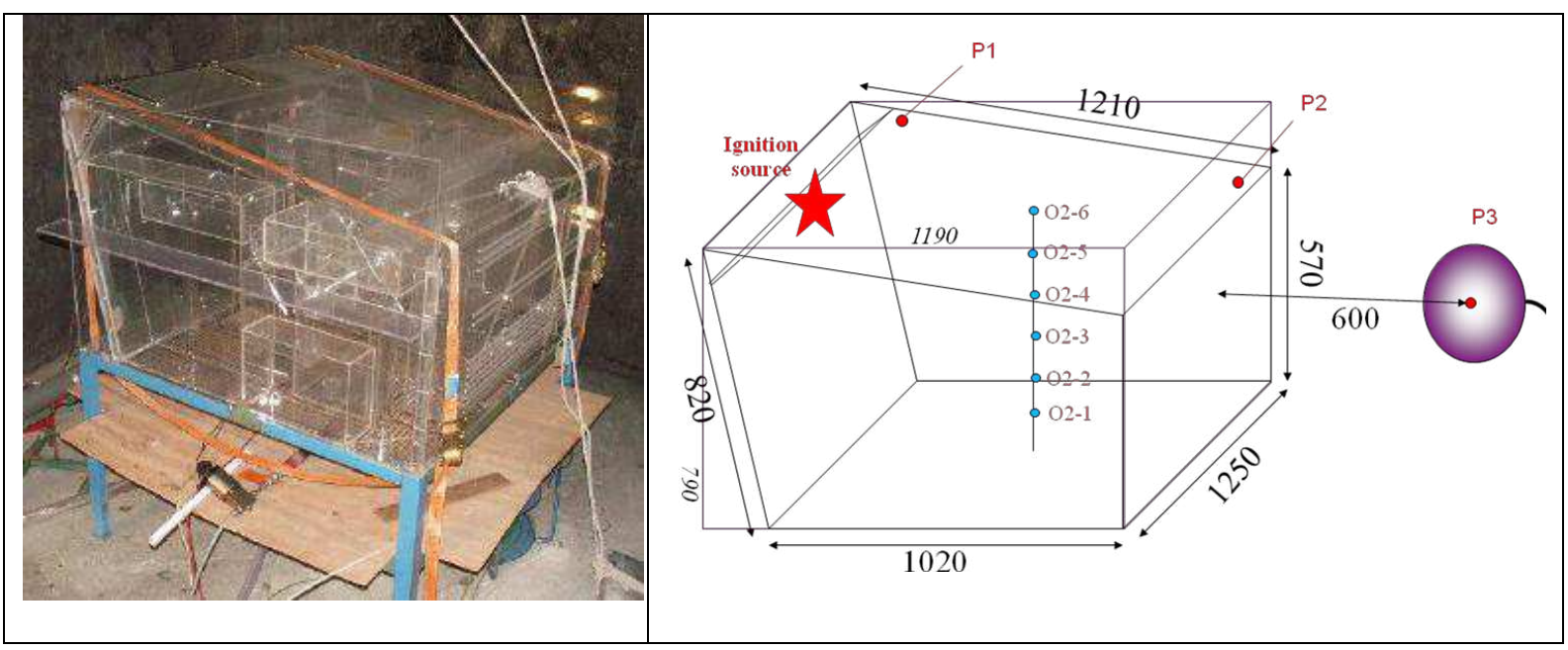

Figure 4. Rig used for the explosion tests

Infrared, normal and high-speed cameras were placed next to the rig. The rig was instrumented with 3 pressure transducers and 6 concentration measurements (Figure 4). Two of the pressure measurements (P1 and P2) were carried out inside the rig while the third pressure (P3) was measured outside the rig 
at $600 \mathrm{~mm}$ in front of the cover grid. It must be indicated that all the tests were performed in windless conditions since the rig was placed in an $80 \mathrm{~m}^{3}$ gallery. Six concentration probes $(\mathrm{O} 2-1 \ldots \mathrm{O} 2-6)$ were positioned on a mast placed at approximately the centre of the rig to control the hydrogen-air mixture before ignition. Injection took place below the rig through an orifice of $8 \mathrm{~mm}$ located at the coordinates $x=625 \mathrm{~mm}, y=500 \mathrm{~mm}$ and $\mathrm{z}=0 \mathrm{~mm}$. This position was chosen to ensure that the ascending gas would not encounter any obstacle before reaching the bonnet. The release flow rate was kept constant at $450 \mathrm{NL} / \mathrm{min}$ and the desired hydrogen-air mixture was obtained by varying the release duration (20 s max.) and, if necessary, by turning on a ventilation fan to homogenise the mixture. During these tests, the investigated parameters were the concentration field (both the average value and the stratification) and the ignition position.

As an example, Figure 5 shows the results obtained when the hydrogen concentration was homogenous and equal to $12.7 \% \mathrm{vol} / \mathrm{vol}$ at the time of ignition. It gives the time-variations of the pressures in P1 and P3 and the distance travelled by the flame. This travelling distance was deduced from the video recordings made during the experiments. Snapshots of this video are shown in Figure 6.

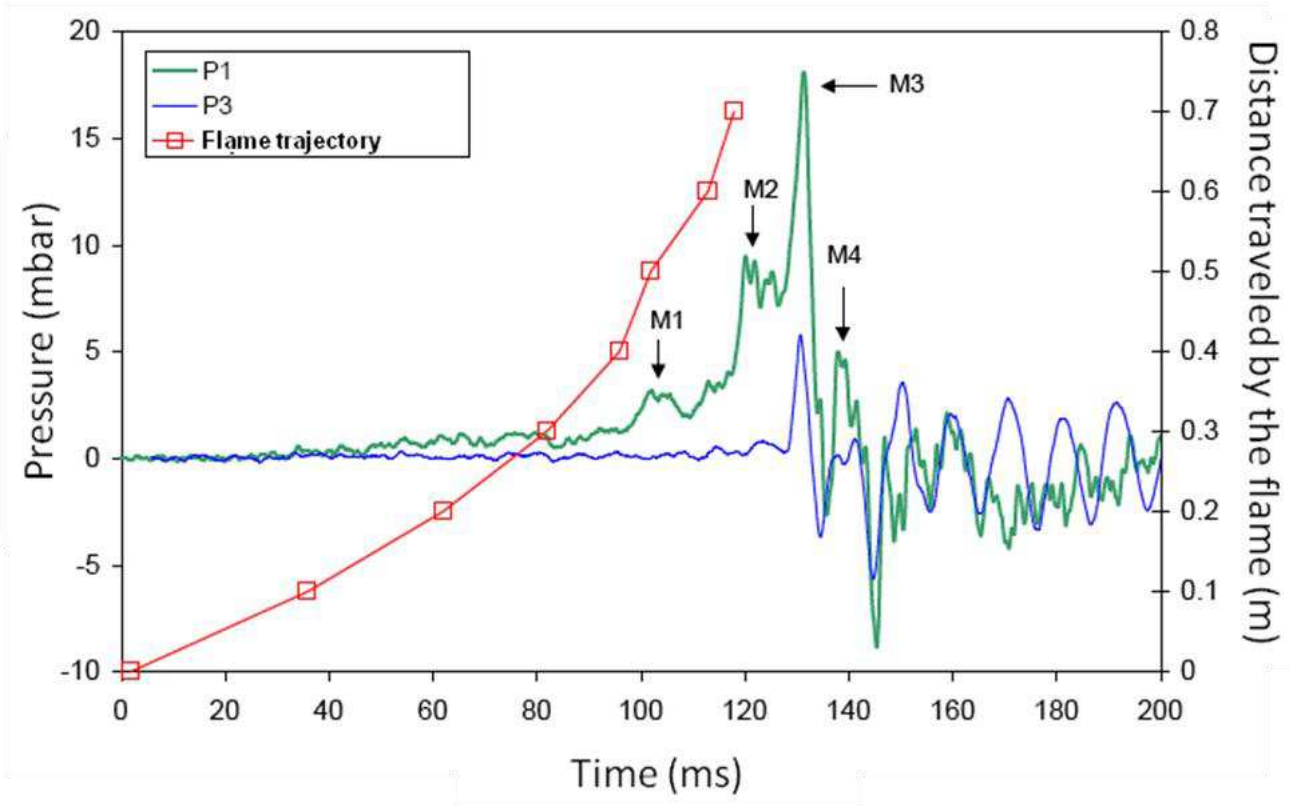

Figure 5. Results obtained with a homogenous hydrogen concentration of $12.7 \% \mathrm{vol} / \mathrm{vol}(=$ test 3 in Table 3)

- The first peak (referred to as M1 in Figure 5) corresponds to the moment when the flame enters a zone where the number of obstacles increases from 2-3 to 7. From that moment, the flame accelerates.

- The second one (M2) appears when the flame enters a zone where the number of obstacles rises from 7 to 10. Again, the flame accelerates.

- While propagating, the flame acts as a piston on the remaining hydrogen-air mixture: part of it is expelled and ignites outside the rig hence creating another external explosion. It might be responsible of the third peak (M3) in the P1 signal and the first peak observed in the P3 signal

- The last peak (M4) is associated with the turbulent combustion of the last pockets of flammable mixtures present between the obstacles. 


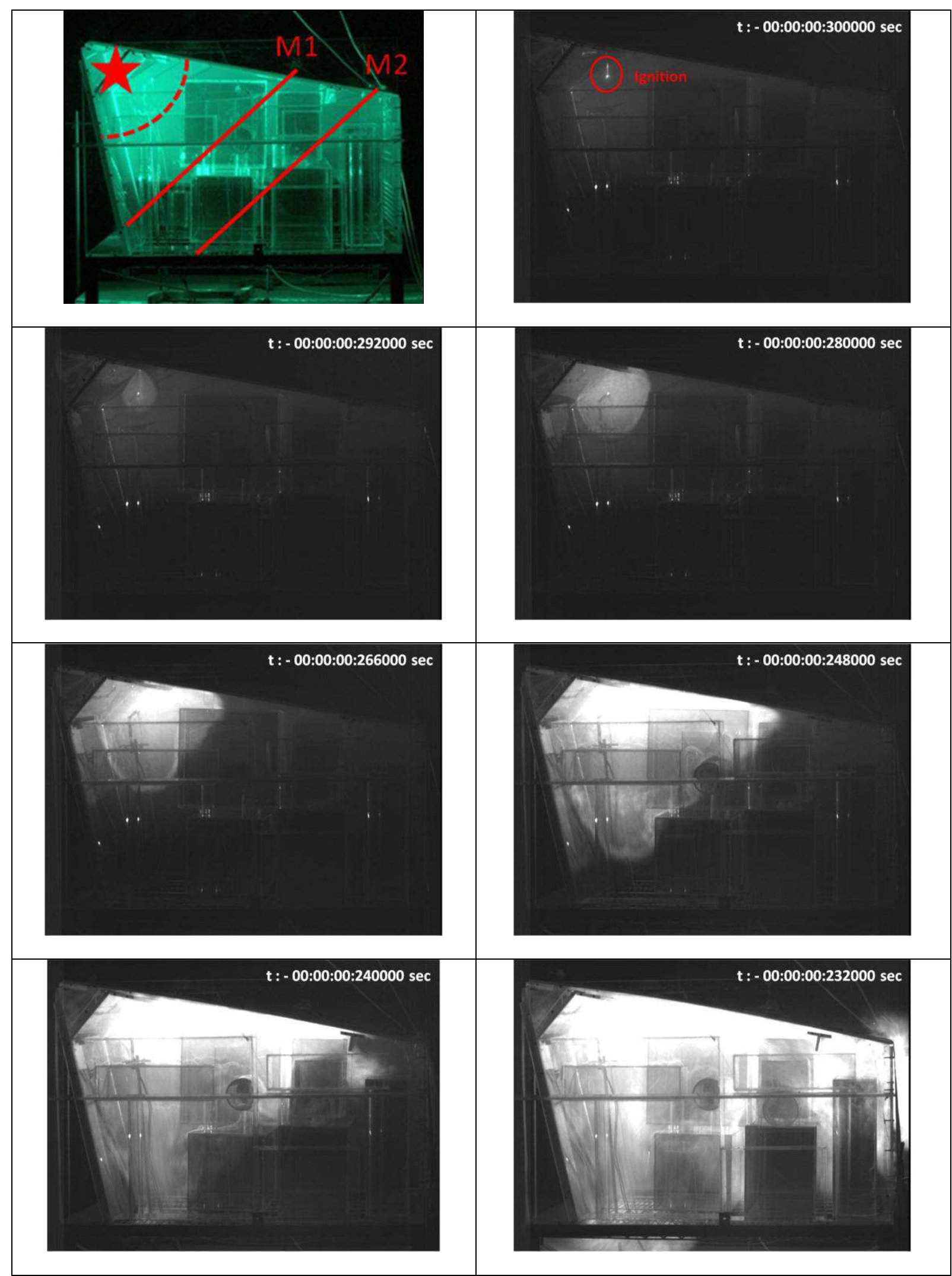

Figure 6. Flame propagation in a homogenous hydrogen concentration of $12.7 \% \mathrm{vol} / \mathrm{vol}(=$ test 3 in Table 3) 
In overall, overpressure was found to be reasonably well correlated with the flame velocity. This velocity depends on the laminar burning velocity and, to a lesser extent, the burnt gas expansion ratio. Both parameters are functions of mixture richness. Consequently, it is not surprising that the measured overpressures were the highest when the ignition took place in the richest layers of the stratified hydrogen-air mixture. In addition, the highest overpressures were obtained when it took longer for the flame to escape from the rig since it implies that the flame met a large number of obstacles hence promoting its acceleration. The possible formation of an external explosion should not be overshadowed. Depending on the flammable mass that has been expelled out of the engine compartment, this second explosion may lead to significant damages outside the vehicle. It is therefore important to fully understand which conditions led to this event since it did not occur for all experiments.

Additional ignition tests were repeated using a real vehicle. Care was taken to place the ignition source and the instrumentation within the engine at approximately the same locations as within the rig (Figure 7). Table 4 compares the experimental results between the two geometries when the ignition source was located close to the windshield. The parameters $\Delta \mathrm{P}_{1,3}$ stand for the overpressure measured at the locations P1 and P3. For a given concentration, the $\Delta \mathrm{Ps}$ measured in the vehicle were found to be slightly higher than those obtained with the rig (compare test ref. 2 and 11 for example): this is mainly due to a difference of filling ratio. One can conclude that the pressure effects are negligible when the averaged hydrogen concentration is below $10 \% \mathrm{vol} / \mathrm{vol}$, which would imply a maximum leakage flow rate in the engine compartment of about $10 \mathrm{NL} / \mathrm{min}$ based on Figure 3. Note that this tolerable value might be exceeded by an accidental leakage but also, looking back at Table 2, by a chronic leakage caused by insufficient tightening.
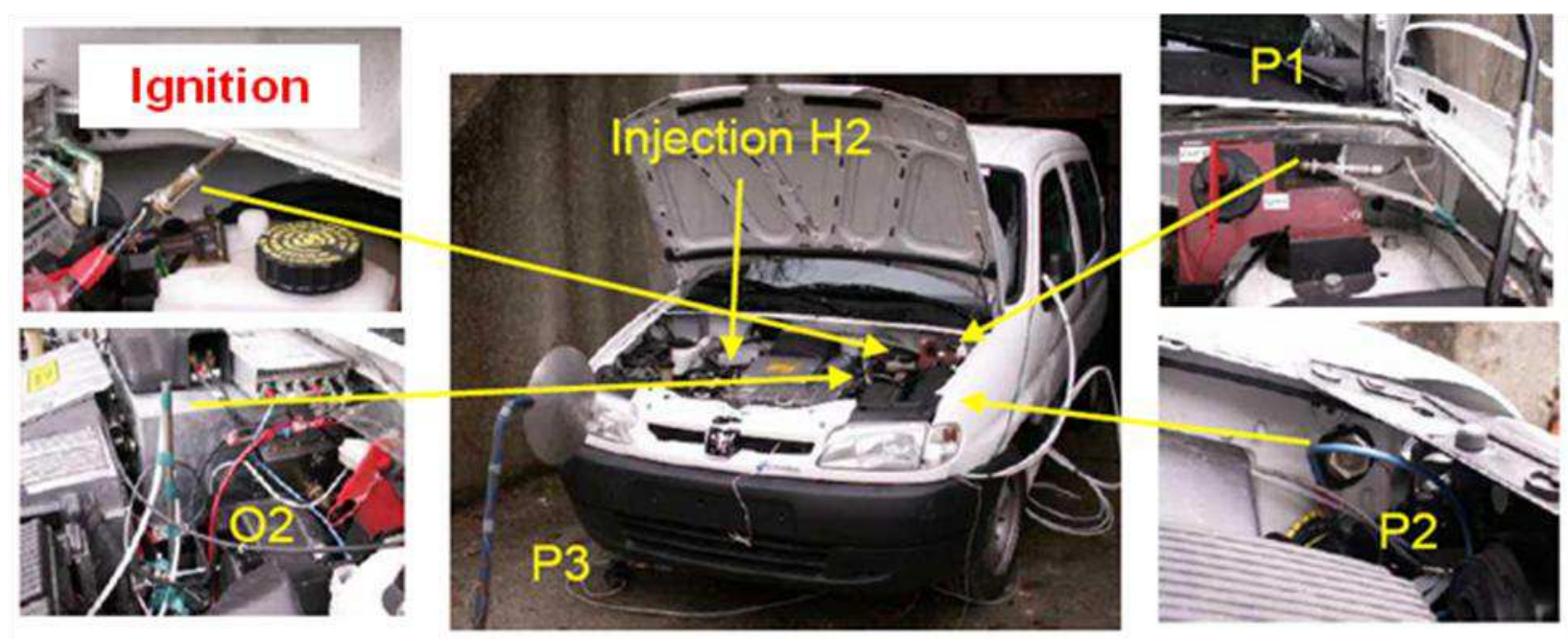

Figure 7. Instrumented vehicle for the explosion tests

As far as the vehicle is concerned, only minor deformations were observed during the ignition tests on the front bonnet and bumper, no significant damage was reported in the engine compartment and no damage was observed in the passenger compartment. These observations are in agreement with MAEDA [17]. 
Table 3. Testing conditions and main results obtained during the ignition tests [19].

\begin{tabular}{|c|c|c|c|c|c|}
\hline \multirow{2}{*}{ Test ref. } & \multirow{2}{*}{ Stratified? } & Averaged $\left[\mathbf{H}_{\mathbf{2}}\right]$ & {$\left[\mathbf{H}_{\mathbf{2}}\right]$ at ignition } & $\Delta \mathbf{P}_{\mathbf{1}}$ & $\Delta \mathbf{P}_{\mathbf{3}}$ \\
\cline { 3 - 6 } & & {$[\mathbf{\%} \mathbf{v} / \mathbf{v}]$} & {$[\mathbf{\%} \mathbf{v} / \mathbf{v}]$} & {$[\mathbf{m b a r}]$} & {$[\mathbf{m b a r}]$} \\
\hline $\mathbf{1}$ & $\mathrm{N}$ & 6.9 & 8.3 & $\mathrm{NE}$ & $\mathrm{NE}$ \\
\hline $\mathbf{2}$ & $\mathrm{N}$ & 10.6 & 13.3 & 3.0 & 1.6 \\
\hline $\mathbf{3}$ & $\mathrm{N}$ & 12.7 & 16.4 & 19.8 & 8.7 \\
\hline $\mathbf{4}$ & $\mathrm{Y}$ & 8.3 & 15.3 & 4.5 & 1.0 \\
\hline $\mathbf{5}$ & $\mathrm{Y}$ & 11.7 & 20.2 & 97.4 & 29.7 \\
\hline $\mathbf{9}$ & $\mathrm{N}$ & 6.5 & $\mathrm{ND}$ & $\mathrm{NE}$ & $\mathrm{NE}$ \\
\hline $\mathbf{1 0}$ & $\mathrm{N}$ & 7.9 & $\mathrm{ND}$ & $\mathrm{NE}$ & $\mathrm{NE}$ \\
\hline $\mathbf{1 1}$ & $\mathrm{N}$ & 10.3 & $\mathrm{ND}$ & 6.4 & 2.3 \\
\hline $\mathbf{1 2}$ & $\mathrm{N}$ & 15.9 & $\mathrm{ND}$ & 245.8 & 35.6 \\
\hline $\mathbf{1 3}$ & $\mathrm{N}$ & 14.6 & $\mathrm{ND}$ & 170.6 & 63.4 \\
\hline
\end{tabular}

\section{Information:}

Uncoloured cells: data coming from the rig

Gray-coloured cells: data coming from the real vehicle

$\mathrm{NE}$ : data within the uncertainty of the measurement or recording failed during tests

ND: no data

\subsection{HYDROGEN STORAGE}

To provide an acceptable travelling range, car manufacturers tend to connect several tanks together and to store gaseous hydrogen at a pressure as high as 700 bars. Hydrogen storage is usually mounted under the luggage area near the rear axle to minimise the damage in case of an accident [9]. Moreover, the tanks are normally designed to withstand very high internal pressure making them crashworthy [20]. But the external parts of the tanks (piping...) could be more vulnerable and, in case of an accident, could result in a high-pressure ignited leakage.

Tank bursting due to a bonfire is also a serious concern. Testing in real conditions [21] showed that a tank explosion may generate lethal effects up to $10 \mathrm{~m}$ around the vehicle and project fragments at distances up to $100 \mathrm{~m}$. To avoid this, each tank will have to be protected by a Pressure Relief Device (PRD) whose dimensioning (number per tank, direction, opening diameter...) is still an open question [22]. But can it be an acceptable solution? Would the flame anchored to the PRD still be tolerable?

Motivated by the lack of data $[23,24,25,26]$, the DRIVE project and the European project HYPER decided to investigate this topic [27, 28, 29]. Gaseous hydrogen was stored in a type-4 container $(25 \mathrm{~L})$ before being released through a 4,7 and $10 \mathrm{~mm}$ nozzle orifice via a $15 \mathrm{~mm}$ inner diameter and $5 \mathrm{~m}$ long flexible pipe for moderate pressures (up to $100 \mathrm{bar}$ ) and through a 1, 2 and $3 \mathrm{~mm}$ nozzle orifice via a $10 \mathrm{~mm}$ inner diameter and $5 \mathrm{~m}$ long rigid pipe for the highest pressures (from 100 to 900 bars). Blow-down was triggered using a remotely-operated valve situated just upstream of the orifice and the jet issued horizontally $1.5 \mathrm{~m}$ above the ground level. A propane-air Maecker burner was used to ignite rapidly the hydrogen jet. The flame geometry (length, width) was investigated using 
infrared and normal cameras whereas its thermal properties were studied by means of C-type thermocouples and flux meters.

Results for the visible flame length are plotted in Figure 8. The comparison of the visible and infrared pictures shows that the most-radiating part of the flame has a shape similar to that of the visible flame. The flame width was found to be about $1 / 6$ of its length. This is consistent with the observations already made by [23].

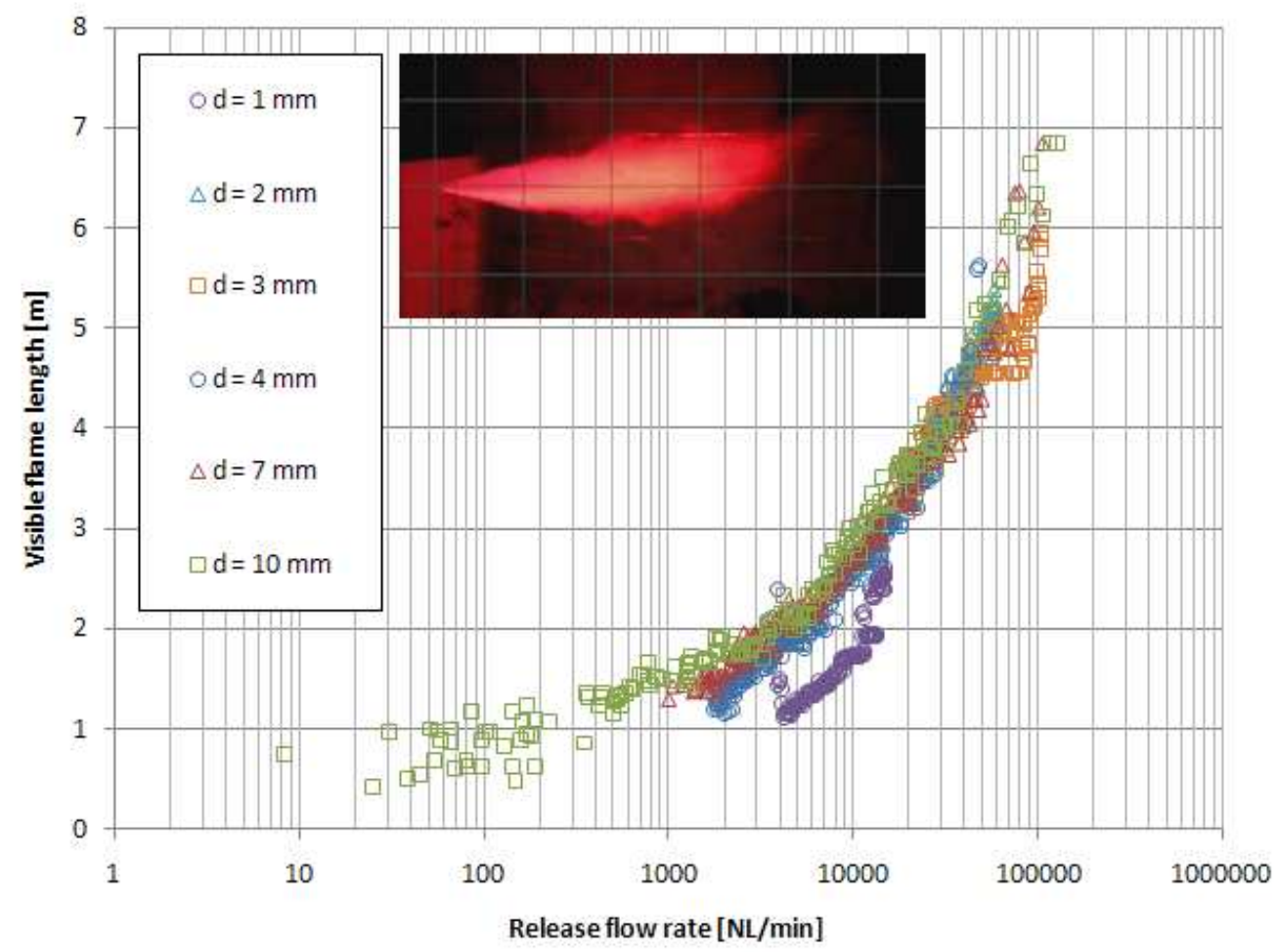

Figure 8 . Visible flame length as a function of the release flow rate

Humans approaching the fuel cell vehicle will be vulnerable to a potential hydrogen flame because of engulfment or thermal radiation. Since temperatures up to $1500^{\circ} \mathrm{C}$ were measured within the flame, a person fully or substantially engulfed by the flame will suffer fatality. Outside the flame, there is some risk due to thermal radiation. A calculation was carried out using a solid flame model ${ }^{3}$ to simulate the functioning of a 2-mm PRD installed on 25-L tank initially storing hydrogen at 900 bars. It was found that the lethal and irreversible effects were reached at a distance of $1-2 \mathrm{~m}$ from the flame surface.

Given all this evidence, safety distances in the order of $10 \mathrm{~m}$ would have to be considered during a bonfire to protect humans from the PRD-induced jet flame. Although it might be possible to mitigate this risk even more by impacting the PRD venting on an obstacle (ground, car bodywork...) [30], one has to wonder whether this would be enough to gain public acceptance. At this stage, it is worth mentioning the recent bonfire tests conducted by INERIS on type-4 reservoirs which led to promising results: the reservoirs never exploded nor generated an ignited jet but simply leaked. This could be an interesting alternative approach to mitigate the risk of tank bursting.

\footnotetext{
${ }^{3}$ This model is often used in process safety applications. It is based on the equation $\Phi(\mathrm{x})=\Phi_{0} \cdot \mathrm{F}(\mathrm{x})$ where $\Phi(\mathrm{x})$ is the radiative heat flux received by the person at a specified distance $\mathrm{x}, \Phi_{0}$ an average value of thermal radiation flux emitted by the flame and F the geometrical view factor. Here, the shape of the flame is chosen to be a horizontal cylinder of length and diameter equal to that observed during the DRIVE experiments. No account was taken of the atmospheric transmissivity.
} 


\subsection{CONCLUSION}

Hydrogen-fuelled vehicles will only be accepted by the population if all risks associated with the use of such flammable gas are completely identified and fully controlled. However, one must admit that the relevant literature is relatively poor on that subject. This motivated the DRIVE consortium to investigate the whole reaction chain leading to accident when hydrogen is used onboard a vehicle.

Three types of leakage were identified:

- Permeation leakage: this leakage takes place permanently but the release flow rate is usually so low that passive safety means (clever design of the engine compartment, ventilation, detection...) should be sufficient to control the risk associated with such leakage.

- Accidental leakage: this leakage is due to an accident or a failure in the process or storage equipment. It can lead to massive leakage (>100 NL/min) but is very rare. Active safety means, such as a calibrated orifice or an excess flow valve, should be installed by the car manufacturer.

- Chronic leakage: it arises because of ageing of vehicle or a succession of maintenance operations. This leakage is more problematic since it features a high probability of occurrence and a release flow rate that could be as high as $100 \mathrm{NL} / \mathrm{min}$.

If a leakage takes place directly in the engine compartment, the resulting hydrogen-air mixture may encounter an ignition source and it was found that pressure effects will be negligible if the averaged concentration is less than $10 \% \mathrm{vol} / \mathrm{vol}$ in hydrogen. Based on dispersion experiments carried out by the DRIVE project, this concentration will not be exceeded if the leakage flow rate is less than $10 \mathrm{NL} / \mathrm{min}$. Note that an accidental leakage but also some chronic leakages (= insufficient tightening due to bad maintenance) could easily reach this maximum tolerable value. Of particular importance is the possible formation of a secondary explosion outside the vehicle following an explosion taking place inside the engine. Since this secondary explosion was not always observed during the experiments, the conditions leading to its formation will have to be clearly identified in the future as it can result in significant damages around the vehicle. The DRIVE partners, alongside with AIR LIQUIDE and HELION, are now involved in another French national project called DIMITHRY, partly aimed at answering this important issue.

As far as the Pressure Relief Device (PRD) is concerned, it becomes evident that safety distances of the order of $10 \mathrm{~m}$ would have to be considered during a bonfire to protect humans from the PRDinduced jet flame. Although it is possible to mitigate this risk even more by impacting the PRD venting on an obstacle, this might be insufficient to gain public acceptance and other means need to be found to mitigate this risk.

\subsection{ACKNOWLEDGMENTS}

The authors are very grateful to all the persons involved in the experimental and numerical tasks of the DRIVE project. They also want to thank the French National Research Agency (ANR), and more particularly its hydrogen programme PAN-H, for its financial support.

\subsection{REFERENCES}

1. BREITUNG W., "Mechanistic Safety Analysis of Hydrogen Based Energy Systems", $2^{\text {nd }}$ Summer School on Hydrogen Safety, 2007.

2. FMCSA, «Guidelines for use of hydrogen fuel in commercial vehicles », Final report of Federal Motor Carrier Safety Administration, FMCSA-RRT-07-020, 2007. 
3. BARLEY C.D., GAWLIK K., OHI J. and HEWETT R., "Analysis of buoyancy-driven ventilation of hydrogen from buildings", International Conference on Hydrogen Safety, San Sebastian, 2007.

4. FÜRST S., DUB M., GRUBER M., LECHNER W. and MÜLLER C., "Safety of hydrogenfuelled motor vehicles with IC engines", International Conference on Hydrogen Safety, Pisa, 2005.

5. CaFCP, "Support facilities for Hydrogen-Fuelled Vehicles - Conceptual Design and Cost Analysis Study", Technical Report conducted by Parsons Brinckerhoff for the California Fuel Cell Partnership, 2004.

6. PERRETTE L., PAILLERE H. and JONCQUET G., "Presentation of the French national project DRIVE: Experimental Data for the Evaluation of hydrogen Risks onboard vehicles, the Validation of numerical tools and the Edition of guidelines", Society of Automotive Engineers, 2007.

7. SCHEFER R.W., HOUF W.G., SAN MARCHI C., CHERNICOFF W.P. and ENGLOM L., "Characterization of leaks from compressed hydrogen dispensing systems and related components", International Journal of Hydrogen Energy 31, pg 1247-1260, 2006.

8. TCHOUVELEV A.V., CHENG Z., AGRANAT V.M. and ZHUBRIN S.Z., "Effectiveness of small barriers as means to reduce clearance distances", International Journal of Hydrogen Energy 32, pg 1409-1415, 2007.

9. ADAMS P., BENGAOUER A., CARITEAU B., MOLKOV V. and VENETSANOS A.G., "Allowable hydrogen permeation rate from road vehicles", International Journal of Hydrogen 36 , page 2742-2749, 2011.

10. VENETSANOS A.G., PAPANIKOLAOU E., CARITEAU B., ADAMS P., BENGAOUER A., « Hydrogen permeation from $\mathrm{CGH} 2$ vehicles in garages : CFD dispersion calculations and experimental validation », International Journal of Hydrogen Energy 35, page 3848-3856, 2010.

11. CARITEAU B., BRINSTER J., TKATSCHENKO I., «Experiments on the distribution of concentration due to buoyant gas low flow rate release in an enclosure », International Journal of Hydrogen Energy 36, page 2505-2512, 2011.

12. GUPTA S., BRINSTER J., STUDER E. and TKATSCHENKO I., "Hydrogen related risks within a private garage: concentration measurements in a realistic full scale experimental facility", International Journal of Hydrogen Energy 34, page 5902-5911, 2009.

13. CARITEAU B., BRINSTER J., STUDER E., TKATSCHENKO I. and JONCQUET G., «Experimental results on the dispersion of buoyant gas in a full scale garage from a complex source », International Journal of Hydrogen Energy 36, page 2489-2496, 2011.

14. CARITEAU B., "Projet PAN-H DRIVE: Synthèse des essais réalises avec l'installation GARAGE du CEA sur le rejet d'hélium en milieu confine stimulant des fuites d'hydrogène", Livrable I.2.2 du projet DRIVE, SFME/LEEF/RT/08-027/A, 2009.

15. LINDEN P.F., "The fluid mechanics of natural ventilation", Annu. Rev. Fluid Mech., 31:20138, 1999.

16. MAEDA Y. et al., "Test of Vehicle Ignition due to Hydrogen Gas Leakage", SAE Technical Paper Series, SP-1990, page 1-7, 2006. 
17. MAEDA Y., ITOI H., TAMURA Y., SUZUKI J. and WATANABE S., "Diffusion and Ignition Behavior on the Assumption of Hydrogen Leakage from a Hydrogen-Fueled Vehicle", SAE Technical Paper Series, 2007-01-0428, 2007.

18. JAMOIS D. and PROUST C., «Fuites d'hydrogène sous capot - rapport d'essai », Livrable II.2.3-B du projet DRIVE, 2009.

19. STUDER E., KUDRIAKOV S., JAMOIS D. and PROUST C., "Projet DRIVE: Formalisation des connaissances sur l'explosion", Livrable II.2.5 du projet DRIVE, 2009.

20. STEPHENSON R.R., "System-level design and verification concepts for hydrogen-fuelled vehicles: fire worthiness", World Hydrogen Energy Conference n¹6, Lyon, 2006.

21. DIGGES K.H. and STEPHENSON R.R., "MVFRI Research Summary: Research in Fire Safety for Hydrogen-Fuelled Vehicles", based on contracts with Southwest Research Institute and FIREXPLO.

22. Society of Automotive Engineers, "Developing Safety Standards for FCVs and Hydrogen Vehicle", SAE J2578 document, 2002.

23. SCHEFER R.W., HOUF W.G., BOURNE B. and COLTON J., "Spatial and radiative properties of an open-flame hydrogen plume", International Journal of Hydrogen Energy 31, pg 1332-1340, 2006.

24. MOLINA A., SCHEFER R.W. and HOUF W.G., "Radiative fraction and optical thickness in large-scale hydrogen jet fires", Proceedings of the Combustion Institute 31, page 2565-2572, 2007.

25. MOGI T. and HORIGUCHI S., "Experimental study on the hazards of high-pressure hydrogen jet diffusion flames", Journal of Loss Prevention in the Process Industries 22, page 45-51, 2008.

26. IMAMURA T., HAMADA S., MOGI T., WADA Y., HORIGUCHI S., MIYAKE A. and OGAWA T., "Experimental investigation on the thermal properties of hydrogen jet flame and hot currents in the downstream region", International Journal of Hydrogen Energy 33, page 3426-3435, 2008.

27. JAMOIS D. and PROUST C., «Caractérisation expérimentale de fuites enflammées d'hydrogène - rapport d'essai », Livrable II.2.3-A du projet DRIVE, 2009.

28. PROUST C., JAMOIS D. and STUDER E., "High-pressure hydrogen fires", International Journal of Hydrogen 36, page 2367-2373, 2011.

29. BRENNAN S., BENGAOUER A., CARCASSI M., CERCHIARA G., EVANS G., FRIEDRICH A., GENTILHOMME O., HOUF W., KOTCHURKO A., KOTCHOURKO N., KUDRIAKOV S., MAKAROV D., MOLKOV. V., PAPANIKOLAOU E., PITRE C., ROYLE M., SCHEFER R., STERN G., VENETSANOS A., VESER A., WILLOUGHBY D. and YANEZ J., "Hydrogen and Fuel Cell Stationary Applications: key findings of modelling and experimental work in the HYPER project", International Conference on Hydrogen Safety, Ajaccio, 2009.

30. HOUF W., SCHEFFER R., EVANS G., KELLER J. and MOEN C., "Recent research and development on barrier wall for mitigation of unintended releases of hydrogen", Presentation of the National Hydrogen Association Meeting, Sacramento, 2008. 